\title{
Theories of Maritime Education and Training (MET) in Improving Maritime Sector in Malaysia
}

\author{
Noorlee Boonadir ${ }^{1}$, Rosnah Ishak ${ }^{2}$, Hamidah Yusof ${ }^{2}$, Aida Fakhrul Lamakasauk ${ }^{3}$ \\ ${ }^{1}$ Maritime Management Section, Malaysian Institute of Marine Engineering Technology, Universiti Kuala Lumpur, Lumut, \\ Malaysia \\ ${ }^{2}$ Faculty of Management and Economy, Universiti Pendidikan Sultan Idris, Tanjung Malim, Malaysia \\ ${ }^{3}$ Faculty of Modern Languages and Communication, Universiti Putra Malaysia, Seri Kembangan, Malaysia \\ Email: noorleeboonadir@gmail.com, rosnery.rosnah@gmail.com, hamidah.yusof@fpe.upsi.edu.my, \\ aida.fakhrul@globalturbineasia.com
}

How to cite this paper: Boonadir, N., Ishak, R., Yusof, H., \& Lamakasauk, A. F. (2020). Theories of Maritime Education and Training (MET) in Improving Maritime Sector in Malaysia. Open Journal of Business and Management, 8, 1193-1200. https://doi.org/10.4236/ojbm.2020.83076

Received: January 8, 2020

Accepted: May 16, 2020

Published: May 19, 2020

Copyright () 2020 by author(s) and Scientific Research Publishing Inc. This work is licensed under the Creative Commons Attribution International License (CC BY 4.0).

http://creativecommons.org/licenses/by/4.0/

\begin{abstract}
The Ministry of Education (MOE) should focus on the provision of quality academic programme as awareness to face the trends and challenges in the era-globalization. Maritime education and Training (MET) is presently facing many challenges thus to sustain a pool of qualified and competent profession is at a risk. The strong factors affect the implementation of maritime education and training which may help the MET compete with other education fields in the educational institution. MET execution will be able to produce manpower that equip with the skills and knowledge with quality exposure either for maritime education institution.
\end{abstract}

\section{Keywords}

Academic Programme, Maritime Education and Training (MET), Educational Institution

\section{Introduction}

The management of education and training in the extensively provides enhancement for growth, expansion and positive change to face the challenges in this maritime industry. It provides knowledge and awareness as well as the different choice to individuals for the industry. For most of the industries, there is a need for qualified and competent human resources management for continuity and sustainability. In many jurisdictions, MET is yet to be implemented, or re- 
mains as concept to generate discussion at the policy level (Haun, 2014). As explained by Haun (2014), the development of MET should provide few subjects that related to the training and skills required by the industries as crew members at the sea or shore side for example in the marine shipyard or port facilities. MET provides knowledge and skills about the shipping industry and related activity which are valuables at the management institution level once the pedagogical approach is applied in the appropriate context and level of education.

\section{Background of the Study}

The volume of exported and imported goods through sea transportation amounted to $98.4 \%$ with RM 1.48 trillion of the total trading by shipping is a significant contributor to the Malaysia economy (MOT, 2016). Hence there is an increasing demand for maritime services including shipping, port management, transportation linkages and related activities constantly. Based on the Malaysia Shipping Master Plan 2017-2022, the government emphasized the development of the Maritime Education and Training Blueprint because the industry required the skillful and expert manpower to boost up the development of this sector (MOT, 2016).

The development and growth in maritime industry have a significant impact on the economy of Malaysia. The maritime industry expands impressively in Malaysia. Our country was listed in the global market as per reported in The Global Competitiveness Index 2016-2017 Rankings show that Malaysia was at the 25th place among the 138 countries around the world for a long-term growth. This competiveness is able to generate the economy growth and constancy as a container transshipment hub in the region and a market leader in handling and exporting oil and gas products. Base on the Figure 1, the trend in Cargo throughput by Malaysia ports extremely increase yearly from export,

\begin{tabular}{ccccccccccc}
\hline Year & 2009 & 2010 & 2011 & 2012 & 2013 & 2014 & 2015 & 2016 & 2017 & 2018 \\
\hline Million Tones & 395 & 450 & 498 & 501 & 511 & 542 & 570 & 569 & 545 & 568 \\
\hline
\end{tabular}

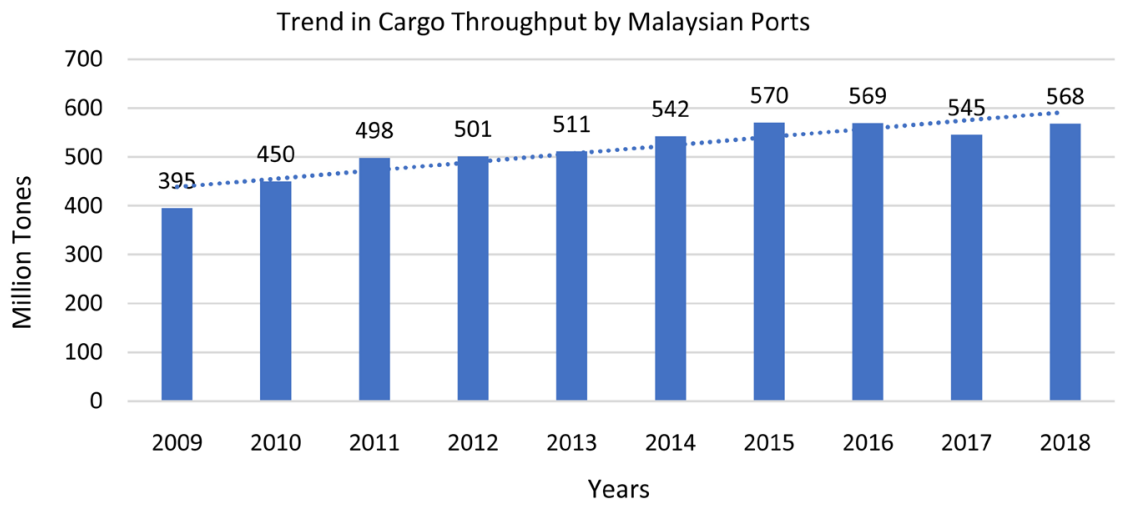

Figure 1. Trend in cargo throughput by Malaysian ports. Sources: Port Klang Authority (2018). 
import and transshipment. Over the last ten years' Malaysian ports have recorded an average growth of $3 \%$ in compound cargo throughput. Following a drop in 2017 due to a change in the shipping line market and overall lows in global seaborne trade, cargo throughput recovered in 2018 totaling at 568 million tons. About $70 \%$ of the cargo is containerized. With a total throughput of 24.9 million TEUs in 2018, Malaysian ports handled almost as many containers as the ports of Rotterdam and Antwerp combined. While the majority is transshipment, cargo that does not enter the country, Malaysian exports and imports accounted for respectively 4.5 and 4.4 million TEUs in throughput. Last but not least, as one of world's largest liquefied natural gas (LNG) exporters, Malaysia is home to the first floating LNG port facility and the largest palm oil terminal in the world.

Currently, there are 13 major ports were built in Malaysia and the largest port is Port Klang followed by Port Tanjung Pelepas. It is strategically located along the world's busiest shipping route which was the Straits of Malacca Westport as a regional hub, national load center of Port Klang and one of the most competitive port in the world. Compared to other ports in Malaysia (Port Klang Authority, 2018), Port Klang was ranked among the top 20 container ports in the world and has trade links with over 120 countries and more than 500 ports and Westport commands $62 \%$ share of the container volume in Port Klang, Malaysia and deal with more than 500 ports throughout the world as per shown in Table 1 (Bernama, 2016).

\section{Issues and Challenges}

Malaysia workers and crew need to attend for education and training for skills and knowledge improvement besides understand and practice more English

Table 1. Ranking of Malaysia port (in thousands TEU).

\begin{tabular}{ccccccccc}
\hline Ranking & Port & $\mathbf{2 0 1 8}$ & $\mathbf{2 0 1 6}$ & $\mathbf{2 0 1 5}$ & $\mathbf{2 0 1 4}$ & $\mathbf{2 0 1 3}$ & $\mathbf{2 0 1 2}$ & $\mathbf{2 0 1 1}$ \\
\hline $\mathbf{1}$ & Port Klang & 11,978 & 13,170 & 11,887 & 10,736 & 10,350 & 10,000 & 9600 \\
$\mathbf{2}$ & Tanjung Pelepas & 8261 & 8281 & 9120 & 8500 & 7628 & 7700 & 7500 \\
\hline
\end{tabular}

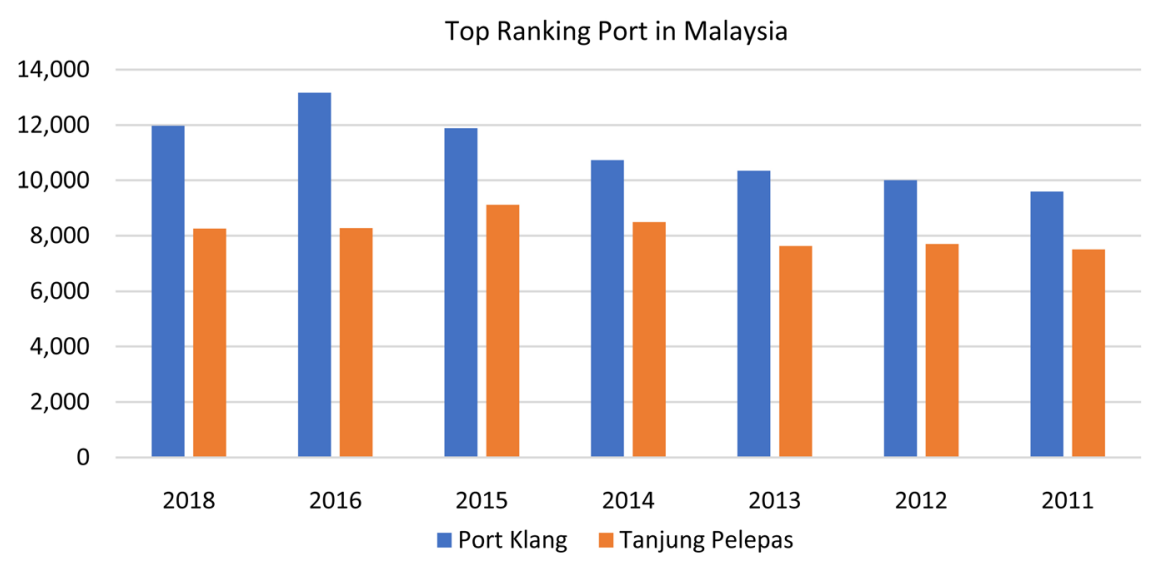

Sources: Lloyd's list top 100 ports 2018, 2018. 
Communication in the maritime field. Referring to the results from a few scholars concluded the communication English issues affect to implement the MET in educational institutions such as communicating in English with an adequate level of the language during the training and education session. Principally, safety of the crew at sea and ports, maintenance effectiveness of working environment required maritime English education.

Referring to the ILMIA (2017), the demand for the workforce for Maritime sector in Malaysia shows the highest full-time vacancy rate for the year 2017. As at overall rate, $11 \%$ is for skilled positions, next $9 \%$ by semi-skilled and lastly $4 \%$ by low-skilled. The total overall was differentiated into two types of vacancies which are Shipbuilding and Ship Repairs (SBSR). The highest figure of skilled crews highlighted that SBSR required potential personnel that have knowledge, practical and well trained while semi-skilled should grow their position to the next level per listed in Table 2.

Based on Figure 2, it shows the analysis of the workforce that have been provided with training on total respondents of $56 \%$ cited while $44 \%$ was not given the experience yet. It is clear that the training is their recent and targeted initiative to attract, maintain and develop employees. The provision of training divided into three sub-sector that consist of shipbuilding, ship repairs and others. All this sectors show most probably the demand service in marketplace. If the industry faces with shortage of knowledgeable and skillful workforce, it will affect the port development and the growth of the maritime industry in Malaysia.

In the future, the factors of MET implementation become more important because of the human element highlighted in shipping industry. This is not just

Table 2. Vacancy rate of shipbuilding and ship repairs 2017.

\begin{tabular}{cccc}
\hline Level & Overall & Shipbuilding & Ship Repair \\
\hline Skill & $8 \%$ & $8 \%$ & $3 \%$ \\
Skilled & $11 \%$ & $10 \%$ & $1 \%$ \\
Semi-Skilled & $9 \%$ & $10 \%$ & $9 \%$ \\
Low-Skilled & $4 \%$ & $5 \%$ & $0 \%$ \\
\hline
\end{tabular}

Vacancy rate of Shipbuilding and Ship Repairs 2017

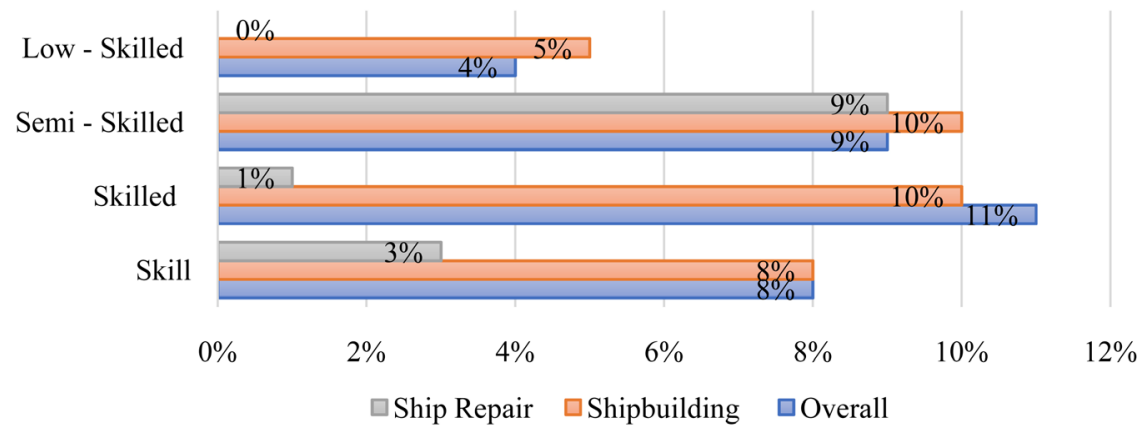

Sources: ILMIA, 2017. 


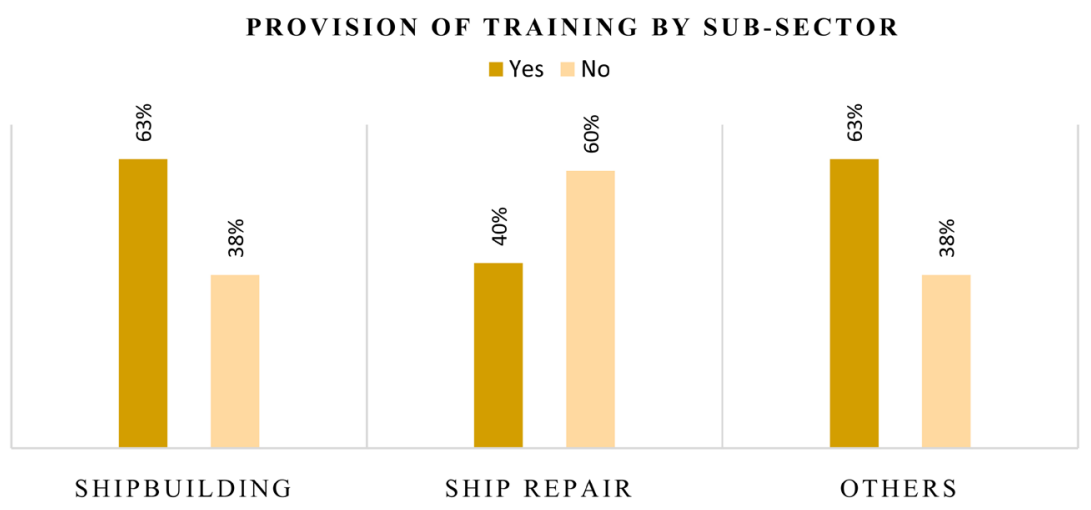

Figure 2. Provision of training of shipbuilding and ship repairs 2017. Sources: ILMIA, 2017.

for commercial reasons but also for the industry to move forwards to the higher standards of safety, environmental impact, and sustainability. It is the human element that will interpret new objectives in these areas into solid actions and solution to make the industry more competitive and well-develop. Without a quality labor force, motivated, trained, and skilled as per required in appropriate international standards, shipping industries are unable to thrive successfully. After all the advances have been made in terms of safety and environmental impact, it can reach to the risky position if personnel were not being trained well within the industry and incapable to engage them properly.

\section{Literature Review}

The competence and trained workers are important and necessary for the maritime industry which identified costly and challenging (Othman, 2014). It depends on the Malaysia Maritime Cluster which managed to strengthen the Maritime Human Capital sustainability. The existing of a strong maritime education basis with effective policy development could be recognize and mobilize by the creation of sustainable maritime academic programs and subjects based on future demand and requirement. Mapping of the maritime education in Malaysia universities which has been carried out to identify the relevance and viability courses or subject play the role to guide and can be adopted for this education phase (Othman, 2014). Hence, there was an increased demand for maritime services including shipping, port management, transportation linkages and other maritime activities such as pipeline, offshore and oil. Therefore, it required skill and expertise manpower or workforce to boost up the expansion in the industry for the future. The government makes an effort to emphasize the development of the maritime industries, especially in shipping and port management sectors (BNM, 2003).

This highlighted industry attracted the researcher to explore the scope of studies which have been conducted on the necessity and expectations from the government, industries especially from education institutions and education policy for the future plan. In line with the contribution of MET for the industry, 
it is important to assure that the workforce and new entrants have the experience in the right education and field, knowledge and skills that should guide the expertise to involve with the technologies and right procedures to face the challenges of evolution 4.0. This phase of challenges will growth fast as world trade continues to expand and enhance the shipping activities accordingly (IMO, 2013).

Based on Figure 3, Maritime Human Resource \& Maritime Education Training was part of the maritime strategy development. Human resources describe as people in organization, possess with range of capabilities, talents and attitudes. As per stated in Malaysia Shipping Master Plan 2017-2022, strategic human resources required to expand and build up the maritime industry. This aspect related to employees' development, in terms of recruitment stage and continues while interviewing potential candidates and seafarers in order to select the best employees for the maritime company (Belev, 2015). The other maritime strategy is education and training which is necessity either formal or informal structure. A curriculum revision is one of the scope in reorienting MET towards sustain maritime development. The curriculum designated to provide students with knowledge and skills required to build and improve their qualification and competency. These practical aspects define that the aim and learning outcomes of a course or subjects have to be relevant to placement of responsibilities describes by the way the maritime industry operates and its needs. Therefore, industry demand could create the curriculum design and education in general, where MET institutions are providers of maritime human resources. In broader context, MET is considered to be the pathway of science and a qualification of advancements in the maritime industry (Prylipko, 2016). As to be professionals or experts, they need to maintain and keep develop themselves updated and follow the latest modern information, knowledge and technologies which required to support their individual capability that generates into team structure towards the industry.

Apart from education and training, the other elements need is the level of the full implementation of the Standard of Training, Certification, and Watch keeping (STCW) 1978/2010 Convention required to be shown in teaching and training programs at Maritime institutions. The institutions also should fit the requirement of national and international Framework Qualifications to guarantee the education syllabus that offered meet the international standard and level job market activity (Mindykoowski, 2013).
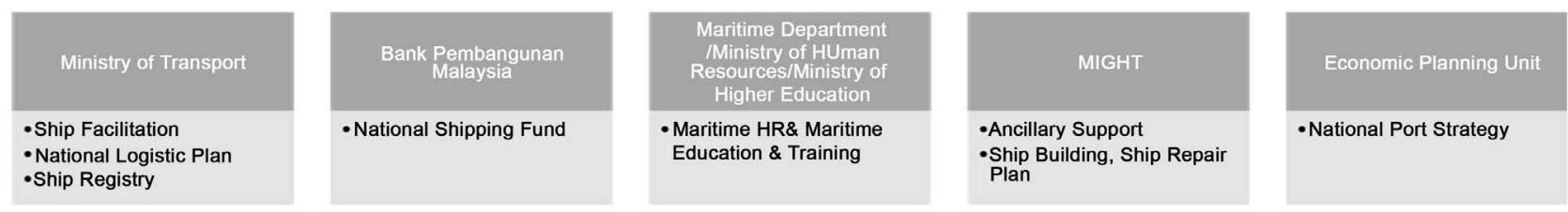

Figure 3. Malaysia maritime strategy. Malaysia Shipping Master Plan 2017-2022 "Revitalizing shipping for a stronger economy ministry of transport", 2017. 


\section{Discussion}

The main objective for this research was to identify that the present maritime education can be classified as traditional mode with limited knowledge and motivation in order to explore more in maritime education. Currently, there was insufficient education and training applied to the institutions or at working level. This situation formed an opinion that a career in shipping is required to commit and understand with the whole life at sea and the coastal which was agreed by Baylon and Santos (2012). It is being supported by Haun (2014) and also agreed with that issue regarding the jurisdictions. One of the key aspects in reorienting MET towards sustainable maritime development should be curriculum revision. A broadly accepted vision of curriculum design is that its first and foremost purpose is to equip students with knowledge and skills required to build/improve their qualification and competence. Thus, curriculum design and education in general are considered as derived from industry demand, where MET institutions are suppliers of maritime human resources. Needless to say, the overall aim of a curriculum in such a scenario would be to fit the existing processes of the maritime industry. Therefore, designing and implementing a curriculum related to sustainable development imposes considerable challenges on MET institutions. Firstly, it requires a reorientation of institutional policy and a review of the overall aim of education. Secondly, it examines the understanding of sustainable development by management and educators along with their critical approach towards existing practices. If these challenges are overcome successfully, knowledge and skills in sustainable development might be introduced in MET as a separate bachelor's or master's programme, as an additional course in existing programmes or a topic within the most relevant course.

In reality position, MET institutions need to design the conceptualization to generate the discussion since it is still at a beginning stage which is new to Malaysia culture. In order to execute with complete implementation according to the syllabus structure, the evolution of maritime industries in Malaysia is related closely with economic growth proved by the shipping industry as a significant contributor to Malaysia economy. In 2016, the total trade was RM1.48 trillion. 98.4\% of Malaysian trade is carried by the sea (Malaysia Shipping Master Plan, 2017-2022) of which intellectual preparation and knowledge awareness are more important. This element was prepared purposely for effective understanding towards the globalization in these industries. According to M. Othman (2014), if Malaysia targeted to become well-develop in maritime nation, it should be supported with a knowledge-based economy, and productivity-driven growth and afford to enhance competitiveness proactively. The strong maritime education and training offered were the root course to manage the Maritime Cluster and to sustain the human resources in local or global marketplace. Policy development in MET needs to be aligned with the requirement of academic programs to offer, prepare and fulfil the future demands. MET is an important element in ensuring the growth and sustainability of the maritime industry. 


\section{Conflicts of Interest}

The authors declare no conflicts of interest regarding the publication of this paper.

\section{References}

Baylon, A. M., \& Santos, V. E. (2012). The Challenges in Philippine Maritime Education and Training. International Journal of Innovative Interdisciplinary Research, 1, 34-36.

Belev, B. (2015). Strategic Human Resources Management in the Maritime Knowledge Based Organization. Bulgaria: Nikola Vaptsarov Naval Academy.

Bernama, T. (2016). Port Klang Has Capacity to Handle Almost 20 Million TEUs by 2016. ASEAN Ports Association Malaysia (MAPA).

BNM Bank Negara Malaysia (2003). Report.

Haun, E. (2014). Grants Offered for Maritime History Projects.

IMO (2013). World Maritime Day, a Concept of a Sustainable Maritime Transportation System: A Concept of a Sustainable Maritime Transportation System.

Institute of Labour Market Information and Analysis (ILMIA) (2017). The Maritime Sector Workforce Ship Building and Ship Repairs. Putrajaya, Malaysia: Ministry of Human Resources.

Malaysia Shipping Master Plan (2017-2022). Revitalizing Shipping for a Stronger Economy. Putrajaya: Ministry of Transport, Malaysia.

Mindykoowski, J. (2013). Advances in Maritime Education and Training: The Case of New Competencies of Electro-Technical Officers Complying with International Regulations. Journal of Maritime Research, 11, 13-19.

Ministry of Transport Malaysia (MOT) (2016). http://www.mot.gov.my

Othman, M. R. (2014). UMT's Future Maritime Education Programs in Enhancing Malaysian Competitiveness in the Maritime Industry. Journal of Business and Social Development, 2, 9-19.

Port Klang Authority (2018). Port Klang Authority's Official Portal. Malaysia.

Prylipko, A. (2016). The Paradigm of Sustainable Development in Maritime Education and Training (Vol. 22, pp. 1-9). 